\title{
Development of Improved Cellulase Variants for the Conversion of Spent Mushroom Substrate Supplemented with Wheat Straw by Directed Evolution
}

\author{
Valentina Mauriello \\ University of Naples Federico II \\ Anna Pennacchio \\ University of Naples Federico II \\ Irantzu Alegria Dallo \\ National Renewable Energy Centre (CENER) - Biomass Department \\ Laura Garcia Saez \\ National Renewable Energy Centre (CENER) - Biomass Department \\ Petri Ihalainen \\ MetGen Oy Rakentajantie 26 \\ Antoine Mialon \\ MetGen Oy Rakentajantie 26 \\ Valeria Ventorino \\ University of Naples Federico II, University of Naples Federico II \\ Vincenza Faraco ( $\nabla$ vfaraco@unina.it ) \\ University of Naples Federico II
}

\section{Research Article}

Keywords: Cellulase, Streptomyces, directed evolution, saccharification, spent mushroom substrate

Posted Date: August 3rd, 2021

DOI: https://doi.org/10.21203/rs.3.rs-763119/v1

License: (c) (i) This work is licensed under a Creative Commons Attribution 4.0 International License. Read Full License 


\section{Abstract}

To improve the Spent mushroom substrate (SMS) saccharification, cloning, recombinant expression in Escherichia coli and characterization of two new GH5 family cellulases (Cel1 and Cel2) were performed. Based on enzymes properties, Cel2 was selected for the generation of 30,000 random mutants by directed evolution in order to develop improved biocatalysts. Error-prone Polymerase Chain Reaction was used for diversity generation in cel 2 gene and the screening for activity of mutants allowed selection of 63 improved variants that were subjected to a scale up production. Among these, 13 clones exhibited twofold higher activity than Cel 2 and a higher thermoresistance after $72 \mathrm{~h}$. The performances of these mutants in the hydrolysis of pretreated SMS/ wheat straw (40/60) were compared to the wild type Cel2 in conjunction with a commercial enzymatic mixture (MetZyme® SUNO ${ }^{\text {TM }}$ BOOSTER 144). All the mutants exhibited a glucose yield two-fold or four fold higher than wild-type Cel2 after $72 \mathrm{~h}$ of incubation.

\section{Introduction}

During the last years, with the progress of cultivation technologies, the mushroom production has increased a lot, reaching 35 million tons in 2013 [1][2]. This has caused ecological and economic challenges, linked to the disposal of the by-product spent mushroom substrate (SMS), considering that production of each kilogram of mushrooms generates $5-6 \mathrm{~kg}$ of residual material [3][4]. This has generated interest to find new treatment technologies and new uses of this by-product [4], having high relevance in the perspective of circular economy [5]. In this context, it is noteworthy that the spent mushroom substrate is a lignocellulosic material that can represent a resource for the fermentable sugars production and generation of added-value chemicals and materials [6][2][7][4][8][3][9].

However, nowadays, the production of the second generation biochemicals at competitive levels is currently hindered by the high costs of the major enzymes needed for lignocellulolytic biomass conversion, namely cellulases and hemicellulases [5][10].

To reduce the enzymatic saccharification costs, research and development activities both in academic and industry sectors have focused on the development of more efficient biocatalysts for the lignocellulose hydrolysis, through isolation of new microbes from different habitats or discovery of new enzymes by metagenomic approaches or improvement of the existing ones by genetic engineering [11] [12][10][13][14][15][16].

Bacteria and fungi from different habitats, such as soil [17][13][18], water [19], agricultural wastes [20] [21], compost [22][23] and plants [24][25], represent a large natural reservoir of (hemi)cellulolytic enzymes due to the need of their production for the habitat colonization [15][26].

As showed in our previous communication [25], twenty-four Actinobacteria were isolated from lignocellulose biomasses of Arundo donax, Eucalyptus camaldulensis, Populus nigra naturally subjected to biodeterioration, in order to find microorganisms able to produce biocatalysts for the hydrolysis of pretreated lignocellulosic biomasses. The screening for cellulase activity of these strains allowing to 
select Streptomyces argenteolus AE58P as the best cellulase producer. Moreover, the A. donax, P. nigra and Panicum virgatum pretreated biomasses were successfully hydrolyzed using the extracellular enzymatic mixture of $S$. argenteolus AE58P [25][14]. Therefore, the cellulolytic enzymes of $S$. argenteolus AE58P were identified and among the proteins identified, two proteins (ID 503810539 and 503918330) were revealed to belong to the GH5 family and named Cel1 and Cel2. In this work these two proteins were chosen to be recombinantly expressed and characterized and to select a cellulase for directed evolution experiments. A strategy to generate and screen 30,000 directed evolved mutants of the GH5 cellulase Cel2 from S. argenteolus AE58P was developed and applied, in order to obtain improved biocatalysts in the hydrolysis of pretreated SMS combined with wheat straw.

\section{Materials And Methods}

\section{Strains media and chemicals}

The Escherichia coli Top 10 cells (Invitrogen) were grown in Luria-Bertani (LB) medium (10 g L bactotryptone, $10 \mathrm{~g} \mathrm{~L}^{-1} \mathrm{NaCl}, 5 \mathrm{~g} \mathrm{~L}^{-1}$ yeast extract), using $50 \mu \mathrm{g} \mathrm{ml}^{-1}$ ampicillin.

The heterologous expression was performed using as host the strain E. coli BL21 CodonPlus (DE3) RP (Novagen Ltd). The error-prone (ep) PCR (Polymerase Chain Reaction) mutagenesis was performed by the Gene Morph II Random Mutagenesis Kit (Agilent, La Jolla, California, USA). Restriction enzymes and the buffers were provided by New England Biolabs (Beverly, MA, USA). 4-Nitrophenyl $\beta$-Dglucopyranoside was obtained from Alfa Aesar (Kandel, Germany). Saccharification experiments were performed using the enzymatic commercial mixture used in Pennacchio et al. 2018 [14] and the enzymes were provided by Genencor (Rochester, New York, USA).

The enzymatic mixture MetZyme® SUNO ${ }^{\text {TM }}$ BOOSTER 144 was supplied by MetGen Oy $\left(15 \mathrm{U} \mathrm{ml}^{-1}\right)$.

\section{Gene sequencing}

The new GH5 cellulases encoding genes from Streptomyces argenteolus AE58P, named Cel1 and Cel2, that in proteomics analyses showed peptide sequences matching with proteins with id 503810539 and 503918330, were synthetized by Polymerase chain reaction (PCR ) on S. argenteolus AE58P's genomic DNA, using degenerate oligonucleotides as primers. Primers sequences were designed on the basis of the sequences of peptides identified in our previous work [25].

The degenerate oligonucleotides are reported below. 1 FW/1 REV for the amplification of the central region: (gtc ggc aty gtg ggc ctg ggc/gcc ytc sgg rta rtc ytc gaa aaa and gcg acc acc tty tgy ctg gay gay $\mathrm{gtg} /$ rta sga ctg gtt cag sgg gtt for Cel1 and Cel2, respectively); 2 FW/2 REV for the amplification of the 5' region (atg aay gay gay gtn ccn ggn ggt ctg gac/ ccc cac agy gar tat ccs gay ggc and gct ngc gca sgc scg gcc gtt cag/ cac rtc rtc cag rca raa ggt ggt cgc for Cel1 and Cel2, respectively); 3 FW/3 REV for the 
amplification of $3^{\prime}$ terminal region (ccc cac agy gar tat ccs gay ggc/ sgc ytt scg cca ytc rcc ccg ggt and aac ccs ctg aac cag tcs tay/ gct ngc gca sgc scg gcc gtt cag for Cel1 and Cel2 respectively).

The sequencing of the DNA fragments was performed by Eurofins Genomics Service (Milan, Italy).

Sequences of the genes coding for the new GH5 cellulases Cel1 and Cel2 from S. argenteolus AE58P, are available in the EMBL Data Library (MN845760 and MN845759 respectively).

\section{Cloning and recombinant expression}

Cel1 and Cel2 encoding genes were cloned into pBAD and pET22b (Novagen, Inc.) expression vectors, obtaining Cel1- pBAD, Cel2-pBAD, Cel1-pET22b, Cel2-pET22b and they were expressed in E. coli BL21(DE3) RP (Novargen Ltd).

The cells were grown at $37^{\circ} \mathrm{C}$ in $0.05 \mathrm{~L}$ of $\mathrm{LB}\left(50 \mu \mathrm{g} \mathrm{mL} \mathrm{L}^{-1}\right.$ ampicillin), until optical density (O.D.) 0.7 . Different concentrations of Isopropil- $\beta$-D-1-tiogalattopiranoside, IPTG $(0.01,0.1$ and $0.5 \mathrm{mM})$ and arabinose $(0.002 \%$ and $0.02 \%)$, different incubation times ( 3 hours and overnight) and temperatures $\left(20^{\circ} \mathrm{C}\right.$ and $\left.37^{\circ} \mathrm{C}\right)$ were tested for proteins expression.

The mutant cells were cultured at $37^{\circ} \mathrm{C}$ in $0.05 \mathrm{~L}$ of LB medium with $50 \mu \mathrm{g} \mathrm{mL}^{-1}$ ampicillin until optical density (O.D.) 0.7 and $0.02 \%$ arabinose was used as inducer of the protein expression over night at $20^{\circ} \mathrm{C}$.

The cells were removed by centrifugation of the liquid cultures for 20 minutes at $4^{\circ} \mathrm{C}(6,000 \mathrm{rpm})$. The supernatants of the samples were used to measure the cellulase activity towards 4-Nitrophenyl $\beta-D$ glucopyranoside (Sigma Aldrich, Milan, Italy).

The results correspond to the average of three experiments, everyone in triplicates.

\section{Determination of optimal temperature and $\mathrm{pH}$}

The optimal temperature of the recombinant enzymes was evaluated using 4-Nitrophenyl $\beta-D-$ glucopyranoside dissolved in $0.05 \mathrm{M} \mathrm{Na}$ citrate buffer at $\mathrm{pH} 5$ as substrate, and performing the incubation for 10 minutes at $37^{\circ} \mathrm{C}, 45^{\circ} \mathrm{C}, 50^{\circ} \mathrm{C}, 55^{\circ} \mathrm{C}$ and $60^{\circ} \mathrm{C}$.

The determination of optimal $\mathrm{pH}$ of cellulase activity was performed using the substrate 4-Nitrophenyl $\beta$ D-glucopyranoside, dissolved in $0.05 \mathrm{M}$ citrate phosphate buffers, with $\mathrm{pH}$ values between 4.0 and 6.0 and performing the incubation $(10 \mathrm{~min})$ at $45^{\circ} \mathrm{C}$ and $55^{\circ} \mathrm{C}$ for Cel 1 and Cel2, respectively.

To determine the optimal temperature and optimal pH of cellulase activity for the best mutants, 4Nitrophenyl $\beta$-D-glucopyranoside was dissolved in $0.05 \mathrm{M}$ phosphate buffer at different $\mathrm{pH}$ (4-6), performing the incubation for 10 minutes at $37^{\circ} \mathrm{C}, 45^{\circ} \mathrm{C}, 50,55^{\circ} \mathrm{C}$ and $60^{\circ} \mathrm{C}$. 
The results correspond to the average of three experiments, everyone in triplicates.

\section{Effect of temperature and $\mathrm{pH}$ on the enzyme activity}

To determine the thermoresistance of the recombinant enzymes, 4-Nitrophenyl $\beta$-D-glucopyranoside was dissolved in $0.1 \mathrm{M} \mathrm{Na}$ acetate buffer at $\mathrm{pH}$, performing the assay at $37^{\circ} \mathrm{C}, 45^{\circ} \mathrm{C}, 50^{\circ} \mathrm{C}, 55^{\circ} \mathrm{C}$ and $60^{\circ} \mathrm{C}$ for $72 \mathrm{~h}$.

The determination of $\mathrm{pH}$ resistance of cellulase activity was performed assaying the enzymatic activity with the substrate 4-Nitrophenyl $\beta$-D-glucopyranoside, dissolved in $50 \mathrm{mM}$ citrate phosphate buffers, with $\mathrm{pH}$ values between 3.0 and 7.0, performing the assay by incubation for $10 \mathrm{~min}$ at $45^{\circ} \mathrm{C}$ and $55^{\circ} \mathrm{C}$ for Cel 1 and Cel2, respectively, and monitoring the maintenance of enzymatic activity for 72 hours.

To determine the thermoresistance of the best clones, 4-Nitrophenyl $\beta$-D-glucopyranoside was dissolved in $0.1 \mathrm{M} \mathrm{Na}$ - acetate buffer at the optimal pH of wild type Cel2 $(\mathrm{pH} 5)$, and at the optimal pH of each clone and the incubation was performed at the optimal temperature of each clone and of wild type Cel $2\left(55^{\circ} \mathrm{C}\right)$, for 72 hours, collecting the samples at different times.

The results correspond to the average of three experiments, everyone in triplicates.

\section{Evaluation of substrate specificity}

Substrate specificity of Cel1 and Cel2 was measured towards 4 substrates (4-Nitrophenyl $\beta-D$ glucopyranoside PNPG, azo-CMC, azo-Avicel, filter paper). The substrate pNPG (Sigma Aldrich, Milan, Italy) was dissolved in $0.1 \mathrm{M}$ sodium acetate buffer at pH 5 in a final concentration of $20 \mathrm{mM}$ and it was incubated, with the culture supernatants of $E$. coli recombinantly expressing Cel1 and Cel2, at $45^{\circ} \mathrm{C}$ and $55^{\circ} \mathrm{C}$, respectively, for 10 minutes. After adding $0.5 \mathrm{M} \mathrm{Na}_{2} \mathrm{CO}_{3}$, the absorbance was read at $405 \mathrm{~nm}$. One unit of glycoside hydrolase activity was the measure of enzyme needed to release $1 \mu \mathrm{mol} \mathrm{min}{ }^{-1}$ of $\mathrm{p}$ nitrophenol.

The substrate AZO-CMC (Megazyme, Ireland) was dissolved in $0.05 \mathrm{M} \mathrm{Na}$ - citrate buffer pH 5 to obtain a concentration of $2 \% \mathrm{w} / \mathrm{v}$ and the incubation $\left(50^{\circ} \mathrm{C}\right)$ was performed with the culture supernatants of $E$. coli, expressing Cel 1 and Cel2, for 5 minutes. After adding the precipitating agent and centrifuging at $12,000 \mathrm{rpm}$ for 10 minutes, the absorbance was read at $590 \mathrm{~nm}$ for each sample.

A slurry of the substrate Azo-Avicel in $0.1 \mathrm{M} \mathrm{Na}$ - acetate buffer $(\mathrm{pH} 4.5)$ was incubated for 1 hour in a final concentration of $2 \% \mathrm{w} / \mathrm{v}$, with the culture supernatants of $E$. coli, expressing Cel 1 and Cel2 at $40^{\circ} \mathrm{C}$. The reaction was stopped by $2 \%$ trizma base solution $(\mathrm{pH} \sim 8.5)$. The absorbance was measured at 590 $\mathrm{nm}$, after the centrifugation of the samples for $10 \mathrm{~min}(3,000 \mathrm{rpm})$. 
The activity assay towards Filter Paper (no. 1), purchased from Whatman (Chiltern, UK) was performed as in [14].

The results correspond to the average of three experiments, everyone in triplicates.

\section{Determination of $\mathrm{V}_{\max }$ and $\mathrm{K}_{\mathrm{M}}$}

The kinetics experiments for Cel1 and Cel2 were performed using the substrate 4-Nitrophenyl $\beta$-Dglucopyranoside (pNPG) (1 mM, $10 \mathrm{mM}, 20 \mathrm{mM}, 30 \mathrm{mM}$ and $50 \mathrm{mM})$, dissolved in $0.1 \mathrm{M} \mathrm{Na}$ - acetate buffer ( $\mathrm{pH} 5)$. The culture supernatants of E. coli, expressing Cel1 and Cel2, were incubated with the substrate at their optimal temperature $\left(45^{\circ} \mathrm{C}\right.$ and $55^{\circ} \mathrm{C}$, respectively), for 15 minutes and the absorbance values were measured by taking the readings at $405 \mathrm{~nm}$ every minute and, from these, it was possible to calculate the kinetic constants.

The values of Michaelis-Menten constants $\left(K_{M}\right.$ and $\left.V_{\text {max }}\right)$ of Cel1 and Cel2 were identified using GraphPad software.

The results correspond to the average of three experiments, everyone in triplicates.

\section{Feedstock and feedstock combinations}

Biomass substrates used as raw materials are spent mushroom compost substrate (SMS) and wheat (WS). Spent mushroom compost (solid residue generated after growing mushrooms) and wheat straw were the same materials used in Beckers et al. (2019) [28].

For the development of the assays, feedstock combinations were prepared consisting of a mixture of SMS and WS in a wet weight ratio of $40 \%$ and $60 \%$ (20\% and $80 \%$ in dry basis), respectively.

\section{Thermochemical Pretreatment}

Biomasses were treated at CENER facilities of Biorefinery and Bioenergy Centre (BIO2C), located in Aoiz (Spain). Several thermochemical pretreatment experiments were performed on SMS/WS mixtures with different ratios, considering the recalcitrance of this biomass and allowing to fractionate the biomass into different components in order to obtain valuable bio-based products. The thermochemical pretreatment assays were carried out in the reactor provided by Advancebio Systems LLC, USA as cited by Beckers et al. (2019) [28]. Due to the stickiness behaviour of SMS it was not possible to feed the horizontal continuous reactor automatically, but it worked successfully when SMS was mixed with WS in a 40 to 60 ratio on wet basis. The samples used for this particular study were treated either at $170^{\circ} \mathrm{C}$ and $183^{\circ} \mathrm{C}$ with a fixed residence time $(10 \mathrm{~min})$. Considering that for an optimum performance of the TC pretreatment reactor an initial moisture content of $50 \%$ in the feedstock is required, part of this required 
water can be supplied through SMS addition, reducing the water plant necessities. SMS and WS feedstocks were mixed based on dry matter content and adjusting the moisture up to $50 \%$ by adding the catalyst ( $\mathrm{NaOH} 50 \%$ ) using $2 \%$ of dry weight on the total solid content. This was followed by a manual mixing to reach the homogenisation and before feeding the reactor, the mixture was overnight at room temperature. Indeed, these conditions were part of a broader experimental design for thermochemical fractionation using the feedstock selected (data not shown).

Pretreated samples, generated under the conditions tested, were taken and after collecting a sample for compositional analysis, were subjected to a manual filter press for solid and liquid fraction separation. Solid fraction was store at $4^{\circ} \mathrm{C}$ in zipped plastic bags until being used for enzymatic hydrolysis.

\section{Compositional analysis}

Moisture content in SMS was calculated as in Beckers et al. (2019) [28], following the CEN/TS 147743:2010 procedure. Ash content was determined as mentioned in Beckers et al. (2019) [28]following the UNE-EN IS018122:2015. Elemental analysis of Nitrogen determination is carried out following the UNEEN ISO 16948:2015 and using a conversion factor into protein of 5.25.

Pretreated materials (slurries) were separated to insoluble and soluble fractions, and cellulose, hemicellulose, and lignin contents were quantified from the insoluble fraction by the NREL procedures $n^{\circ}$ 42618 (A. Sluiter, Laboratory Analytical Procedures, (2011). www.nrel.gov/biomass/pdfs/42618.pdf) and $n^{\circ} 42627$ (A. Sluiter, Laboratory Analytical Procedures, (2008).

www.nrel.gov/biomass/pdfs/42627.pdf) respectively. Oligomeric sugars were hydrolysed by adding $72 \%$ $\mathrm{H}_{2} \mathrm{SO}_{4}(\mathrm{w} / \mathrm{w})$, followed by autoclaving at $121^{\circ} \mathrm{C}$ for $1 \mathrm{~h}$. Samples were stored at $-20^{\circ} \mathrm{C}$ until analysis.

Soluble sugar analysis was performed by high-performance liquid chromatography (HPLC), quantifying the content of monosaccharides (d-glucose, d-xylose-fructose-galactose, l-arabinose), disaccharides (cellobiose, maltose) and trisaccharides (maltotriose) as reported in Beckers et al. (2019) [28].

\section{Enzymatic hydrolysis}

Saccharification experiments was performed using pretreated spent mushroom substrate supplemented with wheat straw on a rotary shaker (ThermoMixer C, Eppendorf, Milan, Italy).

The culture supernatants of E. coli recombinantly expressing Cel1 and Cel2 and culture supernatants of Streptomyces argenteolus AE58P [25] were incubated with 10\% (w/v) of dried pretreated biomass in 2.5 $\mathrm{mL}$ of $0.05 \mathrm{M} \mathrm{Na}$ - citrate buffer ( $\mathrm{pH}$ 5). The enzymatic commercial cocktail, used as benchmark, was composed by Accelerase1500, Accelerase BG, and Accelerase XY provided by Genencor and were prepared at the amounts expressed as units per gram of pretreated biomass: 5.4, 145 and 4000, respectively [14]. 
The saccharification yields of Cel1 and Cel2 were tested, replacing Accelerase 1500 with the same amount, in terms of units, of culture supernatants of $E$. coli expressing Cel1 and Cel2 and culture supernatant of $S$. argenteolus AE58P, performing the incubation at $50^{\circ} \mathrm{C}(600 \mathrm{rpm})$. The samples were collected daily until 72 hours and centrifuged at $4^{\circ} \mathrm{C}$ for $30 \mathrm{~min}(6,000 \mathrm{rpm})$. The glucose and xylose released were quantified, analysing the supernatants by high-performance liquid chromatography (HPLC; Dionex, Sunnyvale, CA, USA) as in Ventorino et al. (2016) [25]. Moreover, the saccharification experiments with SMS/WS (40:60) were also carried out using the culture supernatants of $E$. coli recombinantly expressing Cel2 and epCel2 mutants added to the enzymatic mixture MetZyme ${ }^{\circledR}$ SUNO ${ }^{\text {TM }}$ BOOSTER 144 supplied by MetGen Oy. MetZyme ${ }^{\circledR}$ SUNO TM BOOSTER 144 is a high performance booster cocktail custom designed to significantly enhance the cellulose hydrolysis efficiency of cellulases. Three different conditions were tested for two clones and wild type enzyme, to select the best one and apply it to the other mutants, as reported below:

-Condition 1- The enzymatic mixture SUNO TM BOOSTER 144 and the cellulase enzyme (Cel2 wild type or epCel2 mutants) were added to the biomass in the same volume/volume ratio (50:50 V/V-1.5 $\mathrm{U}$ and 0.35 $\mathrm{U}$, respectively).

- Condition 2- $0.54 \mathrm{U}$ of the SUNO TM BOOSTER 144 and $0.54 \mathrm{U}$ of the cellulase enzyme (Cel2 wild type or epCel2 mutants) were added to the biomass.

- Condition 3- $1.08 \mathrm{U}$ of the SUNO TM BOOSTER 144 and $1.08 \mathrm{U}$ of cellulase enzyme (Cel2 wild type or epCel2 mutants) were added to the biomass.

The experiments for the hydrolysis of pretreated SMS/WS were performed incubating the enzymatic cocktails with $10 \%(\mathrm{w} / \mathrm{v})$ of the dried biomass in $2.5 \mathrm{~mL}$ of $0.5 \mathrm{M}$ succinic acid, at the optimal $\mathrm{pH}$ and temperature and of each enzyme on a rotary shaker $(500 \mathrm{rpm})$. The samples were collected daily and until 72 hours and centrifuged at $4^{\circ} \mathrm{C}$ for $30 \mathrm{~min}(6,000 \mathrm{rpm})$. The monosaccharides obtained was quantified analysing the supernatants, by HPLC [25]and the yields of the hydrolysed was expressed in $\mathrm{g} \mathrm{L}^{-}$ 1 .

The results correspond to the average of three experiments, everyone in triplicates.

\section{Construction of Cel2 error-prone PCR library}

pBAD-Cel2 construct was used as target sequence for epPCR and the random mutations were introduced by the Gene Morph II Random Mutagenesis Kit. PCR reactions were performed using the mix and program reported in Cecchini et al. (2018) [29]. About 20 epPCR were performed to obtain $48 \mu \mathrm{g}$ total of Cel2 cDNA, for the construction of the 30,000 mutants library. The DNA regions obtained were purified by the QIAquick Gel Extraction Kit (Qiagen, Hilden, Germany), the digestion with the same restrictions enzymes used for Cel2 was performed and the cloning into a pBAD vector was carried out. The mixture obtained after the ligation was employed for E. coli TOP10 cells transformation, plated into LB agar 
medium with ampicillin $\left(50 \mu \mathrm{g} \mathrm{mL}^{-1}\right)$ and grown at $37^{\circ} \mathrm{C}$ overnight. Liquid medium LB with $50 \mu \mathrm{g} \mathrm{mL}^{-1}$ ampicillin was added to the plates surface in order to collect the colonies with a scraper. After the cells centrifugation for 10 minutes at $4^{\circ} \mathrm{C}(6,000 \mathrm{rpm})$, the QIAprep Spin Miniprep Kit (Qiagen, Hilden, Germany) was used for plasmid DNA preparation to transform E. coliBL21 (DE3) RP cells for the mutants expression.

The cells were incubated overnight at $37^{\circ} \mathrm{C}$ on LB agar (50 $\mathrm{g} \mathrm{m} \mathrm{mL}^{-1}$ ampicillin), to select the error-prone Cel2 (epCel2) mutants.

\section{Screening of epCel2 mutants library}

The Cel2 mutants were inoculated in LB medium ( $200 \mu \mathrm{L}$ in 96 -well plates), by the robot QPIX 450 (Molecular Devices, LLC, California, USA). The mutants were incubated at $37^{\circ} \mathrm{C}$ overnight and they were screened on solid medium in order to discriminate transformants expressing extracellular cellulase activity from those that do not express it. Therefore, each clone of the library was transferred on $22 \times 22$ cm Q-Tray bioassay plates containing LB Agar, ampicillin $\left(50 \mu \mathrm{g} \mathrm{mL}^{-1}\right)$, the substrate $1 \% \mathrm{w} / \mathrm{v}$ carboxymethylcellulose (CMC) and the inducer $0.002 \% \mathrm{w} / \mathrm{v}$ arabinose using a QPix colony picker with 96 well gridding head (Molecular Devices, Sunnyvale, California).

Several trials of the solid medium assay were performed, incubating the plates at $37^{\circ} \mathrm{C}$ for $2,4,6,8$ hours and overnight. In order to identify the transformants able to degrade $\mathrm{CMC}$, the plates were dyed using a Congo red $(0.1 \% \mathrm{w} / \mathrm{v})$ solution for 15 minutes, followed by 3 washing with $3 \mathrm{M}$ sodium chloride $(\mathrm{NaCl})$. The trials of the solid medium assay were performed three times.

The mutants, forming clear halo around the colony, were selected as positive and they were screened in liquid medium, in order to detect the clones more active than Cel2 towards 4-Nitrophenyl $\beta$-Dglucopyranoside.

To define the best conditions for the enzymes production trials of recombinant expression of Cel2 were performed in microscale, using different concentration of the inducer arabinose $(0.002 \%, 0.02 \%, 0.2 \%)$ and two different time for the adding to the growth medium (at the beginning of the growth, at 0.7 OD). The experiments were repeated three times, and data were reported as means \pm standard deviations.

After the mutants incubation at $37^{\circ} \mathrm{C}$ overnight, $200 \mu \mathrm{L}$ of the cultures were diluted by LB medium ( $800 \mu \mathrm{L}$ in 96 deep-well microplates) with ampicillin $\left(50 \mu \mathrm{g} \mathrm{mL}^{-1}\right)$, using the robot BioMek NXP (Beckman Coulter, California, USA) and the incubation was performed at $37^{\circ} \mathrm{C}$. When the cultures reached $0.7 \mathrm{OD}$, arabinose $(0.002 \% \mathrm{w} / \mathrm{v})$ was used to induce the protein production at $37^{\circ} \mathrm{C}$, overnight.

After centrifugation at $3,000 \mathrm{rpm}$ for 30 minutes at $4^{\circ} \mathrm{C}$, the activity of the clones was analysed towards the chromogenic substrate 4-Nitrophenyl $\beta$-D-glucopyranoside, dissolved in $0.1 \mathrm{M} \mathrm{Na}$ - acetate buffer at $\mathrm{pH}$ 5. The enzymes were incubated with the substrate at $55^{\circ} \mathrm{C}$ (Cel2 optimal temperature) for 10 minutes 
and the absorbance was measured at $405 \mathrm{~nm}$ by the Multi Detection SystemGloMax® Discover System (Promega, Wisconsin, USA).

\section{Results And Discussion}

In our previous communication [25], twenty-four Actinobacteria were isolated from lignocellulose biomasses in order to find microorganisms able to produce biocatalysts for the hydrolysis of pretreated lignocellulosic biomasses. After the screening for cellulase activity Streptomyces argenteolus AE58P was selected as the best cellulase producer. Moreover, the pretreated biomasses were successfully hydrolyzed using the extracellular enzymatic mixture of $S$. argenteolus AE58P [25][14]. Therefore, among the identified cellulolytic enzymes of $S$. argenteolus AE58P, two proteins were revealed to belong to the GH5 family and named Cel1 and Cel2. In this work cloning, recombinant expression in Escherichia coli and characterization of Cel1 and Cel2 were performed for the selection of a cellulase for directed evolution experiments. A strategy to generate and screen 30,000 directed evolved mutants of the $\mathrm{GH} 5$ cellulase Cel2 from S. argenteolus AE58P was developed and applied, in order to obtain improved biocatalysts in the hydrolysis of pretreated SMS combined with wheat straw.

\section{Cloning and heterologous recombinant expression of Cel1 and $\mathrm{Cel} 2$}

Two new GH5 family cellulases, named Cel1 and Cel2, were identified among several cellulolytic proteins from Streptomyces argenteolus AE58P isolated from A. donax, E. camaldulensis and P. nigra in our previous work [25].

The Cel1 and Cel2 encoding genes were synthesized by PCR on S. argenteolus AE58P genomic DNA. For both proteins, DNA fragments of the expected length were obtained, and they were sequenced using specific oligonucleotide primers. cel1 and cel2 genes were cloned into pBAD and pET22b vectors and were expressed in E. coli. Trials of recombinant expression of both enzymes were performed to define the best conditions for the enzymes production, using different concentrations of IPTG and arabinose, different incubation times and temperatures, and using 4-Nitrophenyl $\beta$-D glucopyranoside as substrate to measure the cellulase activity (Supplementary Table S1).

The best condition for both enzymes production was obtained when the genes were cloned into pBAD vector and proteins expression was induced by $0.002 \%$ arabinose for Cel 1 and $0.02 \%$ arabinose for Cel2 at $20^{\circ} \mathrm{C}$, overnight. The culture supernatants of E. coli recombinantly expressing Cel 1 and Cel2, obtained in these conditions, were used for the characterization of the recombinant enzymatic activity.

\section{Characterization of Cel1 and Cel2 recombinant enzymes}




\section{Evaluation of substrate specificity}

Substrate specificity of the recombinant cellulases, Cel1 and Cel2, was analyzed towards 4-Nitrophenyl $\beta$ D glucopyranoside (pNPG), azo-CMC, azo-Avicel, Whatman Filter Paper. Among these, azo-Avicel was the only substrate towards which the two recombinant enzymes did not showed any activity.

The ability of Cel1 and Cel 2 to hydrolyze crystalline regions of cellulose was measured towards the substrate Whatman filter paper. The amount of enzyme that releases $1 \mu \mathrm{mol} \mathrm{mL} \mathrm{m}^{-1} \mathrm{~min}^{-1}$ of glucose was $26.48 \pm 0.03 \mathrm{U} \mathrm{ml}^{-1}$ and $33.64 \pm 0.04 \mathrm{U} \mathrm{ml}^{-1}$, respectively (Supplementary Table S2). These can be considered significant levels compared to the literature. As matter of fact, the FPCase activity measured in this work for both the recombinant enzymes was three-fold (Cel1) and seven-fold (Cel2) higher compared to the endoglucanase JqCel5A $\left(4.8 \pm 0.21 \mathrm{U} \mathrm{mg}^{-1}\right)$, which was cloned from the Actinobacteria Jonesia quinghaiensis and functionally expressed in Escherichia coli Rosetta (DE3) [30]. Moreover, the FPCase activity was 40-fold higher compared to the most active strain (among the nine actinomycetes investigated) tested by Mohanta (2014) [31].

The Azo CMCase activity for Cel 1 and Cel2 $(0.38 \pm 0.04$ and $0.29 \pm 0.05$ respectively) was about three times lower compared to CelStrep enzyme [27], but was in the range of the activity exhibited by Streptomyces argenteolus AE58P after 6 days of fermentation [25].

The activity of Cel1 and Cel2, using 4-Nitrophenyl $\beta$-D glucopyranoside (pNPG) as a substrate, was $2.44 \pm 0.06 \mathrm{U} \mathrm{ml}^{-1}$ and $3.11 \pm 0.16 \mathrm{U} \mathrm{ml}^{-1}$ respectively, about 6 (Cel1) and 10 (Cel2) fold higher compared to Azo-CMCase activity despite the fact that Cel5A -a cellulase belonging to the same family, GH5, of Cel1 and Cel2, was not able to hydrolyze 4-Nitrophenyl $\beta$-D glucopyranoside (pNPG) [32].

Based on these results, 4-Nitrophenyl $\beta$-D glucopyranoside (pNPG) was selected as substrate for the next steps of characterization of Cel1 and Cel2.

\section{Determination of $\mathrm{V}_{\max }$ and $\mathrm{K}_{\mathrm{M}}$}

$\mathrm{K}_{\mathrm{M}}$ and $\mathrm{V}_{\mathrm{max}}$ values for Cel1 and Cel2 were calculated measuring the activity towards different concentrations of 4-Nitrophenyl $\beta$-D-glucopyranoside (pNPG) and plotting the data according to the Michaelis-Menten equations. The $K_{M}$ value for Cel1 was $6.50 \pm 0.31 \mathrm{mM}$ and the $V_{\max } 0.035 \pm 0.002 \mathrm{mM}$ $\mathrm{min}^{-1}$ and for Cel2 $\mathrm{K}_{M}$ was $5.61 \pm 0.20 \mathrm{mM}$ and the $V_{\max }$ was $0.033 \pm 0.01 \mathrm{mM} \mathrm{min}^{-1}$. Both enzymes exhibited higher affinity for PNPG substrate compared to $\beta$-glucosidase from Streptomyces griseus with $\mathrm{K}_{\mathrm{M}}$ and $\mathrm{V}_{\max }$ of $8.6 \pm 0.5 \mathrm{mM}$ and $217 \pm 5.0 \mu$ moles $^{-1} \mathrm{~min}^{-1} \mathrm{mg}$, respectively [33]. Moreover, the kinetic parameters suggested that Cel2 showed higher affinity for PNPG than Cel1.

\section{Determination of optimal temperature and $\mathrm{pH}$}


In order to define the best conditions for the hydrolysis of SMS/WS, the optimal pH and temperature for Cel1 and Cel2 activity were determined towards 4-Nitrophenyl $\beta$-D-glucopyranoside (pNPG). The activity values, reported as $\mathrm{U} \mathrm{ml}^{-1}$, are shown in Fig. $1 \mathrm{a}$ and $1 \mathrm{~b}$. Results show that the optimal temperatures for Cel1 and Cel 2 were $45^{\circ} \mathrm{C}$ and $55^{\circ} \mathrm{C}$, respectively. The behaviour of our enzymes is conforming to those of other bacterial cellulases most of which showed a maximum of activity from $40^{\circ} \mathrm{C}$ to $55^{\circ} \mathrm{C}$ [34] [35] [36].

Moreover, the optimal temperatures of Cel1 and Cel2 were close to the temperature for the higher cellulase activity of $S$. argenteolus AE58P reported in our previous work [25].

In particular, the Cel 1 optimal temperature $\left(45^{\circ} \mathrm{C}\right)$ was close to the optimal temperature of the endoglucanase from Streptomyces sp. B-PNG23 characterized by Azzeddine et al. (2013) [37]. On the other hand, Cel2 showed the maximal activity at the same temperature $\left(55^{\circ} \mathrm{C}\right)$ of the cellulase Cel5A, belonging to GH5 family and characterized by Klippel et al. (2019) [32].

An optimal pH of 5.0 was identified for both Cel1 and Cel2. This is comparable with the cellulase Cel5A [32] and it is close to the optimal pH value reported by Oliveira et al. (2016) [38]. Moreover, in Ventorino et al. (2016) [25] we have demonstrated that the optimal $\mathrm{pH}$ for cellulase activities produced by $S$. argenteolus AE58P is 5.

\section{Effect of temperature and pH on enzyme activity}

Considering that the lignocellulosic substrates bioconversions generally take 72 hours [25][14][39][40][41], it is essential that the adopted enzymes maintain their activity to obtain a high conversion yield of the substrates. Therefore, thermoresistance and $\mathrm{pH}$ resistance of Cel1 and Cel2 enzymes were determined and compared.

As shown in Figure 2A and 2B, performing a one hour incubation the recombinant enzyme Cel1 maintained about $60 \%-70 \%$ of activity for all the tested temperatures and Cel 2 retained about $80 \%$ of activity at $37^{\circ} \mathrm{C}, 45^{\circ} \mathrm{C}, 50^{\circ} \mathrm{C}$. In particular, after 72 hours, both Cel 1 and Cel2 retained the $60 \%$ of activity at $37^{\circ} \mathrm{C}$ and about $40 \%$ and $50 \%$ respectively at $50^{\circ} \mathrm{C}$ (Figure $2 \mathrm{~A}$ and $2 \mathrm{~B}$ ). These values indicate better performance compared to $S$. griseus $\beta$-glucosidase which lost activity after three hours of incubation [33].

The determination of $\mathrm{pH}$ resistance of cellulase activity was performed at $\mathrm{pH}$ values from 3.0 to 7.0 with the incubation time of $10 \mathrm{~min}$ at $45^{\circ} \mathrm{C}$ and $55^{\circ} \mathrm{C}$ for Cel 1 and Cel2, respectively (Figure $2 \mathrm{C}$ and 2D). As shown in Figures $2 \mathrm{C}$ and 2D, Cel 1 maintained about $70-80 \%$ of its initial activity in the $\mathrm{pH}$ range from 4 to 7 after 1 hour of incubation, and kept $60 \%$ of its initial activity after 72 hours of incubation at pH 5 and it lost activity at the other $\mathrm{pH}$ values tested. The Cel1 residual activity at $\mathrm{pH} 5$ after 24 hours of incubation was $80 \%$. The value is comparable to the residual activity of the endoglucanase secreted by Streptomyces capoamusin, evaluated in the $\mathrm{pH}$ range from 3 to 9 at $25^{\circ} \mathrm{C}$ for 24 hours [38]. On the contrary, Cel 2 retained $100 \%$ of its initial activity after 72 hours of incubation at pH 4, 5 and 6 , outperforming endoglucanase secreted by S. capoamusin [38]. 


\section{Spent mushroom substrate pretreatment}

\section{Feedstock compositional analysis and their combination}

The compositional analysis of SMS revealed that its carbohydrate content is relatively low (12 and $6 \%$ for glucan and xylan, respectively) as reported in table 1 . Therefore, in order to increase the carbohydrate content, SMS was combined with another underutilized feedstock: wheat straw (WS). The carbohydrate content of wheat straw was three-fold higher than SMS: the glucan content and the xylan content in WS was 3.5-fold higher than SMS, as reported in table 1.

\section{Table 1}

Compositional analysis of SMS, WS and of the binary mixtures SMS and Wheat straw $(60 \%$ and $40 \%$ in wet basis respectively) Wb: wet basis; DM: dry matter 


\begin{tabular}{|c|c|c|c|c|c|c|}
\hline & $\begin{array}{l}\text { Spent } \\
\text { mushroom } \\
\text { substrate } \\
\text { (SMS) }\end{array}$ & & $\begin{array}{l}\text { Wheat } \\
\text { straw } \\
\text { (WS) }\end{array}$ & & $\begin{array}{l}\text { SMS:WS } \\
170^{\circ} \mathrm{C}, \\
2 \% \\
\mathrm{NaOH}, \\
10 \mathrm{~min}\end{array}$ & $\begin{array}{l}\text { SMS:WS } \\
183^{\circ} \mathrm{C}, \\
2 \% \\
\mathrm{NaOH}, \\
10 \mathrm{~min}\end{array}$ \\
\hline & Avg. & $\% \mathrm{DM}$ & Avg. & $\% \mathrm{~W} / \mathrm{W}$ & Avg. & Avg \\
\hline Moisture (\%wb) & $76.7 \pm 0.1$ & $\begin{array}{l}\text { Extractives } \\
(\% \mathrm{DM})\end{array}$ & $14.8 \pm 2.6$ & $\begin{array}{l}\text { Moisture } \\
\text { (wb) }\end{array}$ & $55.2 \pm 0.2$ & $61.4 \pm 0.9$ \\
\hline Ashes (\%DM) & $28.9 \pm 0.4$ & $\begin{array}{l}\text { Glucan } \\
\text { (\%DM) }\end{array}$ & $34.1 \pm 1.4$ & $\begin{array}{l}\text { INSOLUBLES } \\
\text { (db) }\end{array}$ & & \\
\hline Protein (\%DM) & $11.0 \pm 0.3$ & $\begin{array}{l}\text { Xylan } \\
\text { (\%DM) }\end{array}$ & $20.8 \pm 1.1$ & Glucan (db) & $32.8 \pm 0.6$ & $31.7 \pm 0.4$ \\
\hline Glucan (\%DM) & $11.8 \pm 1.5$ & $\begin{array}{l}\text { Arabinan } \\
(\% \mathrm{DM})\end{array}$ & $2.1 \pm 0.3$ & Xylan (db) & $18.9 \pm 0.5$ & $14.4 \pm 0.3$ \\
\hline Xylan (\%DM) & $5.9 \pm 0.7$ & $\begin{array}{l}\text { Insoluble } \\
\text { Acid Lignin } \\
\text { (\%DM) }\end{array}$ & $14.3 \pm 0.8$ & $\begin{array}{l}\text { Arabinan } \\
(\mathrm{db})\end{array}$ & $1.7 \pm 0.0$ & $0.9 \pm 0.0$ \\
\hline Arabinan(\%DM) & $0.5 \pm 0.0$ & $\begin{array}{l}\text { Acid } \\
\text { Soluble } \\
\text { Lignin } \\
\text { (\%DM) }\end{array}$ & $0.7 \pm 0.0$ & $\begin{array}{l}\text { Al Lignin } \\
(\mathrm{db})\end{array}$ & $20.4 \pm 0.4$ & $19.3 \pm 0.2$ \\
\hline Lignin(\%DM) & $34.0 \pm 0.4$ & $\begin{array}{l}\text { Insoluble } \\
\text { acid Ashes } \\
\text { (\%DM) }\end{array}$ & $0.7 \pm 0.3$ & $\begin{array}{l}\text { AS Lignin } \\
(\mathrm{db})\end{array}$ & $1.0 \pm 0.0$ & $0.8 \pm 0.0$ \\
\hline $\begin{array}{l}\text { Soluble sugar } \\
(\% D M) s\end{array}$ & $6.1 \pm 0.1$ & & & $\begin{array}{l}\text { AS Ashes } \\
(\mathrm{db})\end{array}$ & $2.1 \pm 0.1$ & $1.9 \pm 0.1$ \\
\hline \multirow{5}{*}{$\begin{array}{l}\text { Organic acids } \\
\text { (\%DM) }\end{array}$} & $2.8 \pm 0.0$ & & & Acetyl (db) & $4.9 \pm 0.0$ & $3.1 \pm 0.0$ \\
\hline & & & & $\begin{array}{l}\text { SOLUBLES } \\
(\mathrm{db})\end{array}$ & & \\
\hline & & & & Glucose & $0.7 \pm 0.0$ & $0.9 \pm 0.0$ \\
\hline & & & & Xylose & $1.7 \pm 0.1$ & $3.5 \pm 0.1$ \\
\hline & & & & Arabinose & $0.5 \pm 0.0$ & $0.6 \pm 0.0$ \\
\hline
\end{tabular}

\section{Enzymatic hydrolysis of the lignocellulosic substrate using Cel1 and Cel2}

In order to compare the glucose and the xylose yields of the recombinant enzymes Cel1 and Cel2 in hydrolysis of pretreated SMS - WS (40:60) substrate, the culture supernatant of S. argenteolus AE58P and 
an enzymatic commercial cocktail (Accelerase1500, Accelerase BG and Accelerase XY) were used as benchmarks. The performances of Cel1 and Cel2 in the biomass conversion were investigated by replacing the Accelerase ${ }^{\circledR} 1500$ with the culture supernatants of $E$. coli expressing Cel1 or Cel2 and comparing the yields with those obtained using culture supernatant of $S$. argenteolus AE58P, instead of Accelerase ${ }^{\circledR} 1500$. Reactions were incubated at $50^{\circ} \mathrm{C}(600 \mathrm{rpm})$, which is the condition mostly used for saccharification of celluloytic biomasses and, as reported in our previous work [25], it is the temperature to obtain the higher cellulase activity of $S$. argenteolus AE58P. The samples were collected at $0,24,48$ and 72 hours and the monosaccharides yields were determined by HPLC.

The saccharification yields after 72 hours of incubation of the culture supernatants of $E$. coli recombinantly expressing Cel1 and Cel2, with SMS-WS, give results three times higher than those obtained with the commercial mixture $\left(0.52 \pm 0.03 \mathrm{~g} \mathrm{~L}^{-1}\right.$ of glucose and $0.51 \pm 0.03 \mathrm{~g} \mathrm{~L}^{-1}$ of xylose $)$ as reported in the Supplementary Table S3. Moreover, the amount of glucose and xylose obtained with culture supernatants of $E$. coli recombinantly expressing Cel2 $\left(1.83 \pm 0.06 \mathrm{~g} \mathrm{~L}^{-1}\right.$ of glucose and $0.62 \pm 0.04$ $\mathrm{g} \mathrm{L}^{-1}$ of xylose) were higher than those obtained using the culture supernatants of $E$. coli recombinantly expressing Cel1 (1.5 $\pm 0.04 \mathrm{~g} \mathrm{~L}^{-1}$ of glucose and $0.23 \pm 0.01 \mathrm{~g} \mathrm{~L}^{-1}$ of xylose).

\section{Construction and screening of rCel2 error-prone PCR library}

Cel2 was chosen as template for directed evolution experiments, to develop improved biocatalysts for SMS-WS substrate conversion, considering its higher thermoresistance and saccharification yields compared to Cel1. The first step of the directed evolution strategy was the introduction of random mutations in the Cel2 wild type gene sequence using error-prone PCR (epPCR). Several PCR reactions were performed to obtain the cel2 DNA for the generation of a 30,000 mutants library. The second step included cloning of the randomly mutated forms of the cel 2 gene into the expression vector PBAD and the Escherichia coli strain BL21(DE3) transformation. The third step was the high-throughput screening on solid medium carboxymethyl cellulose $(\mathrm{CMC})$ to discriminate the transformants expressing extracellular cellulase activity from those that don't express it. To determine the conditions of solid medium assay, different trials were performed, and the best condition selected was $4 \mathrm{~h}$ of incubation at $37^{\circ} \mathrm{C}$. Among the investigated 30,000 clones, 943 mutants showed a clear halo around the colonies and were selected for the screening in liquid medium in microscale. To define the best conditions for the library screening through analysis of the enzyme activity production in liquid medium towards 4-Nitrophenyl $\beta-D$ glucopyranoside, different trials of recombinant expression of Cel2 were performed in microscale. The best condition was $0.002 \%$ of arabinose inducer at 0.7 OD (Supplementary Table S4). After the screening in liquid medium, 63 clones showed higher activity than wild type Cel2 and were selected for the scale up of production in $0.05 \mathrm{~L}$ flasks.

\section{Recombinant expression epCel2 mutants in flasks}


After the scale up of production in $50 \mathrm{~mL}$ flasks, from the group of 63 mutants which were selected by the screening in liquid medium, 36 clones showed higher activity compared to wild type Cel2. Mutations of these 36 clones were identified. The ratio of cellulolytic activity of mutants and the wild type cellulase, including the results of mutations are reported in Table 2. Among these 36 mutants, three candidates showed a silent mutation (Cel2.7, Cel2.22, Cel2.31) and 21 clones showed at least two-fold higher activity than wild type Cel2.

Table 2

Ratio of activity of the variants to that of wild-type enzyme and mutations. 


\begin{tabular}{|c|c|c|c|c|c|}
\hline Name & Mutations & $\begin{array}{l}\text { Ratio of activity of the } \\
\text { variants to that of wild-type } \\
\text { enzymes }\end{array}$ & Name & Mutations & $\begin{array}{l}\text { Ratio of activity } \\
\text { of the variants to } \\
\text { that of wild-type } \\
\text { enzymes }\end{array}$ \\
\hline \multirow[t]{2}{*}{ Cel2.1 } & A5S & 1.4 & Cel2.19 & D248E & 2.5 \\
\hline & & & & Y609N & \\
\hline Cel2.2 & R152S & 1.7 & Cel2.20 & G337V & 1.1 \\
\hline Cel2.3 & $\mathrm{D} 255 \mathrm{H}$ & 2.3 & Cel2.21 & P427R & 3.4 \\
\hline Cel2.4 & L399V & 1.7 & Cel2.22 & - & - \\
\hline Cel2.5 & V610M & 2.5 & Cel2.23 & R273S & 2 \\
\hline Cel2.6 & M396R & 1.4 & Cel2.24 & V128I & 2.3 \\
\hline \multirow[t]{2}{*}{ Cel2.7 } & - & - & Cel2.25 & T521S & 2.6 \\
\hline & & & & F853L & \\
\hline \multirow[t]{2}{*}{ Cel2.8 } & A59V & 7.3 & Cel2.26 & V61L & 1.4 \\
\hline & & & & $\mathrm{R} 152 \mathrm{H}$ & \\
\hline \multirow[t]{2}{*}{ Cel2.9 } & S89T & 2.2 & Cel2.27 & $\mathrm{R} 130 \mathrm{H}$ & 3.4 \\
\hline & & & & A276S & \\
\hline \multirow[t]{2}{*}{ Cel2.10 } & G186D & 3 & Cel2.28 & R377C & 6 \\
\hline & & & & Q456R & \\
\hline \multirow[t]{2}{*}{ Cel2.11 } & V128M & 2.5 & Cel2.29 & S91T & 3.6 \\
\hline & & & & G340C & \\
\hline Cel2.12 & P427A & 1.2 & Cel2.30 & I72M & 5 \\
\hline \multirow[t]{2}{*}{ Cel2.13 } & P62A & 1.1 & Cel2.31 & - & - \\
\hline & A246E & & & & \\
\hline Cel2.14 & A336P & 1.3 & Cel2.32 & I30M & 3 \\
\hline Cel2.15 & A580P & 2 & Cel2.33 & D275I & 1.3 \\
\hline Cel2.16 & Y461D & 1.1 & Cel2.34 & K429E & 1.4 \\
\hline Cel2.17 & S89R & 3.4 & Cel2.35 & P62A & 6 \\
\hline Cel2.18 & V61M & 2.7 & Cel2.36 & D275Y & 3 \\
\hline
\end{tabular}




\section{Enzymatic properties of the rCel2 mutants: optimal pH and temperature and thermostability}

21 mutants showed two-fold higher activity compared to wild type Cel2 after the scale up of production and the temperature and $\mathrm{pH}$ for cellulase activities as well as thermoresistance were analysed (Figure 3 and Figure 4). Among these 21 characterized mutants, 13 clones retained their activity after 72 hours of incubation at their optimal temperature (Figure 4).

The mutants Cel2.18, Cel2.19, Cel2.28 and Cel2.29 retained about $80-90 \%$ of activity after 72 hours of incubation. Only four mutants lost the $70 \%$ of activity after 72 hours of incubation and the other enzymes retained at least $40 \%$ of activity after 72 hours of incubation.

\section{Saccharification of pretreated biomass of Spent Mushroom Substrate-Wheat straw by rCel 2 mutants and wild-type enzyme}

To evaluate the performances of the 13 best Cel 2 mutants in the bioconversion of the pretreated biomass, culture supernatants of $E$. coli expressing these mutants were added to MetZyme ${ }^{\circledR} \mathrm{SUNO} \mathrm{TM}^{\mathrm{TM}}$ BOOSTER 144 which is a high performance booster enzyme cocktail custom designed to significantly improve saccharification capabilities of cellulases. These were adopted in hydrolysis of the pretreated biomass SMS/WS (40:60) and the sugar yields were compared to those obtained with the enzymatic extract of $E$. coli expressing Cel2 together with MetZyme ${ }^{\circledR}$ SUNO ${ }^{\mathrm{TM}}$ BOOSTER 144 . In order to define the saccharification conditions, different experiments were performed for Cel2 and two mutants, changing the amount of the enzymatic extracts added to the biomass. In particular, in the third tested condition, $1.08 \mathrm{U}$ of the culture supernatants of E. coli expressing Cel2 wild type or epCel2 mutants and $1.08 \mathrm{U}$ of SUNO TM BOOSTER 144, were added to the biomass. The Cel2 glucose yields, obtained in this condition, were about 1.4-fold higher than the first one and about 2.1-fold higher than the second one as shown in table 3 . The Cel2 xylose yields, obtained using the third condition were at least 4-fold higher than the other conditions. Therefore, the condition 3, was selected as the best one and was applied for all the mutants.

The monosaccharide yields of enzymatic saccharification were estimated on samples collected after 72 $\mathrm{h}$ of incubation and expressed in $\mathrm{g} \mathrm{L}^{-1}$ (Figure 5). It was observed that using Cel 2 with SUNO ${ }^{\mathrm{TM}}$ BOOSTER 144 the glucose and xylose yields were $4.51 \pm 0.3 \mathrm{~g} \mathrm{~L}^{-1}$ and $1.29 \pm 0.13 \mathrm{~g} \mathrm{~L}^{-1}$, respectively, whilst for all the mutants the addition showed an effect on glucose yield at least two-fold higher than wild type Cel2. In particular, Cel2.25 and Cel2.29 exhibited a glucose yield four-fold higher glucose yield compared to Cel2.

It is noteworthy that the substrate mixture of SMS/WS (40:60)- and the pre-treatment conditions adopted in this work were specifically set up for the first time. Since different pre-treatments can greatly affect the 
saccharification yields, it is not possible therefore to carry out a comparison of these conversion performances with those previously reported in literature. However, if we analyse the order of magnitude of the glucose $\left(34.8 \mathrm{~g} \mathrm{~L}^{-1}\right)$ and xylose $\left(1.03 \mathrm{~g} \mathrm{~L}^{-1}\right)$ yields obtained from the SMS saccharification reported in Zhu et al. (2016) [39] and those obtained from the saccharification of WS, reported in Toquero et al. (2014) [41] and Sun et al. (2018) [40], our enzymatic mixtures showed similar performances.

Table 3

glucose and xylose yields after 72 hours of SMS/WS (40:60) saccharification experiments obtained with the three conditions tested, using Cel2 and two mutants added to SUNO BOOSTER 144

\begin{tabular}{|lllllll|}
\hline & Condition 1 & & Condition 2 & & Condition 3 & \\
Enzymes & $\begin{array}{l}\text { Glucose } \\
\text { yield }(\mathrm{g} / \mathrm{L})\end{array}$ & $\begin{array}{l}\text { Xylose } \\
\text { yield }(\mathrm{g} / \mathrm{L})\end{array}$ & $\begin{array}{l}\text { Glucose } \\
\text { yield }(\mathrm{g} / \mathrm{L})\end{array}$ & $\begin{array}{l}\text { Xylose } \\
\text { yield }(\mathrm{g} / \mathrm{L})\end{array}$ & $\begin{array}{l}\text { Glucose } \\
\text { yield }(\mathrm{g} / \mathrm{L})\end{array}$ & $\begin{array}{l}\text { Xylose } \\
\text { yield }(\mathrm{g} / \mathrm{L})\end{array}$ \\
\hline Cel2 & $3.12 \pm 0.07$ & $0.33 \pm 0.01$ & $2.11 \pm 0.01$ & $0.22 \pm 0.02$ & $4.51 \pm 0.3$ & $1.29 \pm 0.13$ \\
Cel2.19 & $5.82 \pm 0.02$ & $0.41 \pm 0.01$ & $5.67 \pm 0.04$ & $1.13 \pm 0.02$ & $9.53 \pm 0.38$ & $2.60 \pm 0.32$ \\
\hline Cel2.28 & $5.20 \pm 0.05$ & $1.55 \pm 0.05$ & $12.10 \pm 0.10$ & $2.04 \pm 0.03$ & $13.36 \pm 0.12$ & $2.66 \pm 0.10$ \\
\hline
\end{tabular}

\section{Conclusion}

Two new cellulases of GH5 family (Cel1 and Cel2) were identified by proteomics as responsible for the cellulase activity of the strain Streptomyces argenteolus AE58P. AE58P was previously isolated from lignocellulose biomasses, in order to discover new microorganisms producing biocatalysts for the hydrolysis of pretreated lignocellulosic biomasses [25]. Cel1 and Cel2 were recombinantly expressed in $E$. coli and were characterized and tested in the enzymatic hydrolysis of pre-treated spent mushroom substrate $(40 \%)$ / wheat straw (60\%). Cel2 was selected for the development of improved biocatalysts by directed evolution, considering the higher thermoresistance and hydrolysis yields than Cel1. The strategy specifically set up for generating a library of 30,000 random Cel2 mutants and performing its automated screening for identifying the most active variants, allowed the selection of 63 improved variants. Among these, 21 mutants showing at least 2-fold higher activity than wild type Cel2 after the scale up production were characterized, and the 13 mutants exhibiting higher thermoresistance after $72 \mathrm{~h}$ were selected and tested in the bioconversion of pretreated SMS/WS compared to wild type Cel2 performance when added to the commercial mixture SUNO ${ }^{\mathrm{TM}}$ BOOSTER 144.

All the mutants exhibited a glucose yield two-fold or four-fold higher than wild-type Cel2, when added to the commercial mixture SUNO TM BOOSTER 144. Moreover, the magnitude order of the saccharification yields of the enzymatic mixtures tested in this work was similar to those reported in literature, but a more specific comparison it wasn't possible considering that the mixture SMS/WS and the pretreatment were set up in this work. 


\section{Declarations}

\section{Acknowledgements}

This work was supported by "Enhanced bioconversion of agricultural residues through cascading use" BIOrescue, funded from the Bio Based Industries Joint Undertaking under the European Union's Horizon 2020 research and innovation programme under grant agreement 720708 .

\section{References}

1. Royse, D. J., Baars, J. \& Tan, Q. Current Overview of Mushroom Production in the World. Edible Med Mushrooms 2010, 5-13. https://doi.org/10.1002/9781119149446.ch2 (2017).

2. Grimm, D. \& Wösten, H. A. B. Mushroom cultivation in the circular economy. App/ Microbiol Biotechnol, 102, ,795-803 https://doi.org/10.1007/s00253-018-9226-8 (2018).

3. Xiao, Z. et al. Anaerobic digestion of spent mushroom substrate under thermophilic conditions: performance and microbial community analysis. Appl Microbiol Biotechnol, 102, 499-507 https://doi.org/10.1007/s00253-017-8578-9 (2018).

4. Rinker, D. L. Spent Mushroom Substrate Uses. Edible Med. Mushrooms, John Wiley \& Sons, Ltd; p. 427-54. https://doi.org/10.1002/9781119149446.ch20 (2017).

5. Liguori, R. \& Faraco, V. Biological processes for advancing lignocellulosic waste biorefinery by advocating circular economy. Bioresour Technol, https://doi.org/10.1016/j.biortech.2016.04.054 (2016).

6. Zhu, H., Sheng, K., Yan, E., Qiao, J. \& Lv, F. Extraction, purification and antibacterial activities of a polysaccharide from spent mushroom substrate. Int J Biol Macromol, 50, 840-843 https://doi.org/10.1016/j.jibiomac.2011.11.016 (2012).

7. Ryden, P. al. Bioethanol production from spent mushroom compost derived from chaff of millet and sorghum. Biotechnol Biofuels, 10, https://doi.org/10.1186/s13068-017-0880-3 (2017).

8. Mohd Hanafi, F. H. et al. Environmentally sustainable applications of agro-based spent mushroom substrate (SMS): an overview. J Mater Cycles Waste Manag, 20, 1383-1396 https://doi.org/10.1007/s10163-018-0739-0 (2018).

9. Zhu, H. J., Liu, J. H., Sun, L. F., Hu, Z. F. \& Qiao, J. J. Combined alkali and acid pretreatment of spent mushroom substrate for reducing sugar and biofertilizer production. Bioresour Technol, 136, 257266 https://doi.org/10.1016/j.biortech.2013.02.121 (2013).

10. Montella, S., Amore, A. \& Faraco, V. Metagenomics for the development of new biocatalysts to advance lignocellulose saccharification for bioeconomic development. Crit Rev Biotechnol, 36, 9981009 https://doi.org/10.3109/07388551.2015.1083939 (2016).

11. Faraco, V. Lignocellulose conversion: Enzymatic and microbial tools for bioethanol production. https://doi.org/10.1007/978-3-642-37861-4 (2013). 
12. Liguori, R. et al. Optimization of Arundo donax Saccharification by (Hemi)cellulolytic Enzymes from Pleurotus ostreatus. Biomed Res Int 2015; https://doi.org/10.1155/2015/951871 (2015).

13. Amore, A. et al. Industrial waste based compost as a source of novel cellulolytic strains and enzymes. FEMS Microbiol Lett, 339, 93-101 https://doi.org/10.1111/1574-6968.12057 (2013).

14. Pennacchio, A. et al. Isolation of new cellulase and xylanase producing strains and application to lignocellulosic biomasses hydrolysis and succinic acid production. Bioresour Technol, 259, 325-333 https://doi.org/10.1016/j.biortech.2018.03.027 (2018).

15. Ventorino, V. et al. Exploring the microbiota dynamics related to vegetable biomasses degradation and study of lignocellulose-degrading bacteria for industrial biotechnological application. Sci Rep, 5, 1-13 https://doi.org/10.1038/srep08161 (2015).

16. López-Mondéjar, R., Algora, C. \& Baldrian, P. Lignocellulolytic systems of soil bacteria: A vast and diverse toolbox for biotechnological conversion processes. Biotechnol Adv, https://doi.org/10.1016/j.biotechadv.2019.03.013 (2019).

17. Ashwani, K., Saida, L. \& Reddy, K. V. Original Research Article Isolation, Screening and Characterization of Cellulolytic bacteria from forest soil sample. 3,679-85(2014).

18. Saha, B., Roy, S. \& Hossen, F. Isolation and Identification of Cellulolytic Bacteria from Soil Sample and Their Antibiogram.7,83-90. https://doi.org/10.12691/ajmr-7-3-3 (2019).

19. Hameed, A. et al. Oricola cellulosilytica gen. nov., sp. nov., a cellulose-degrading bacterium of the family Phyllobacteriaceae isolated from surface seashore water, and emended descriptions of Mesorhizobium loti and Phyllobacterium myrsinacearum. Antonie van Leeuwenhoek, Int J Gen Mol Microbiol, .107, 759-771 https://doi.org/10.1007/s10482-014-0370-6 (2015).

20. Kulkarni, N., Vaidya, T. \& Rathi, G. Optimization of cellulase production by Aspergillus species under solid state fermentation. 193 Pharma Innov J, 7, 193-196 https://doi.org/10.22271/tpi (2018).

21. Imran, M., Anwar, Z., Irshad, M., Asad, M. J. \& Ashfaq, H. Cellulase Production from Species of Fungi and Bacteria from Agricultural Wastes and Its Utilization in Industry: A Review. Adv Enzym Res, 04, 44-55 https://doi.org/10.4236/aer.2016.42005 (2016).

22. De Marco, Ã. G., Heck, K., Martos, E. T. \& Van Der Sand, S. T. Purification and characterization of a thermostable alkaline cellulase produced by Bacillus licheniformis 380 isolated from compost. $A n$ Acad Bras Cienc, 89, 2359-2370 https://doi.org/10.1590/0001-3765201720170408 (2017).

23. Nallusamy, S., Amira, A. Z., Saif, A. B., Abdulkhadir, E. \& Elsadig, A. E. Isolation and characterization of cellulolytic Bacillus licheniformis from compost. African J Biotechnol, 15, 2434-2446 https://doi.org/10.5897/ajb2016.15641 (2016).

24. Madhaiyan, M. et al. Paenibacillus polysaccharolyticus sp. Nov., a xylanolytic and cellulolytic bacteria isolated from leaves of Bamboo Phyllostachys aureosulcata. Int J Syst Evol Microbiol, 67, 2127-2133 https://doi.org/10.1099/ijsem.0.001901 (2017).

25. Ventorino, V. et al. Lignocellulose-adapted endo-cellulase producing streptomyces strains for bioconversion of cellulose-based materials. Front Microbiol, 7, 1-15 https://doi.org/10.3389/fmicb.2016.02061 (2016). 
26. Raj, J. \& Isolation Screening, and Characterisation of Cellulolytic Bacteria, Determination of Their Cellulolytic Potential. Int J Adv Res Ideas Innov Technol, .3, 215-220 (2017).

27. Amore, A. et al. Cloning and recombinant expression of a cellulase from the cellulolytic strain Streptomyces sp. G12 isolated from compost. Microb Cell Fact11, 1. https://doi.org/10.1186/14752859-11-164 (2012).

28. Beckers, S. J. et al. From Compost to Colloids - Valorization of Spent Mushroom Substrate. ACS Sustain Chem Eng, 7, 6991-6998 https://doi.org/10.1021/acssuschemeng.8b06710 (2019).

29. Cecchini, D., Pepe, O., Pennacchio, A., Fagnano, M. \& Faraco, V. Directed evolution of the bacterial endo- $\beta-1,4$-glucanase from Streptomyces sp. G12 towards improved catalysts for lignocellulose conversion. AMB Express, .8, https://doi.org/10.1186/s13568-018-0602-7 (2018).

30. Lin, L. et al. A novel pH-stable, endoglucanase (JqCel5A) isolated from a salt-lake microorganism, Jonesia quinghaiensis. Electron J Biotechnol, 24, 56-62 https://doi.org/10.1016/j.ejbt.2016.09.004 (2016).

31. Kishore Mohanta, Y. Isolation of Cellulose-Degrading Actinomycetes and Evaluation of their Cellulolytic Potential. Bioeng Biosci, 2, 1-5 https://doi.org/10.13189/bb.2014.020101 (2014).

32. Klippel, B. et al. Characterization of a thermoactive endoglucanase isolated from a biogas plant metagenome., https://doi.org/10.1007/s00792-019-01099-3 (2019).

33. Kumar, P., Ryan, B. \& Henehan, G. T. M. $\beta$-Glucosidase from Streptomyces griseus: Nanoparticle immobilisation and application to alkyl glucoside synthesis. Protein Expr Purif, 132, 164-170 https://doi.org/10.1016/j.pep.2017.01.011 (2017).

34. Zhang, F., Zhang, X. M., Yin, Y. R. \& Li, W. J. Cloning, expression and characterization of a novel GH5 exo/endoglucanase of Thermobifida halotolerans YIM $90462 \mathrm{~T}$ by genome mining. J Biosci Bioeng, 120, 644-649 https://doi.org/10.1016/j.jbiosc.2015.04.012 (2015).

35. Islam, F. \& Roy, N. Screening, purification and characterization of cellulase from cellulase producing bacteria in molasses. BMC Res Notes, 11, https://doi.org/10.1186/s13104-018-3558-4 (2018).

36. Prasad, P., Singh, T. \& Bedi, S. Characterization of the cellulolytic enzyme produced by Streptomyces griseorubens (Accession No. AB184139) isolated from Indian soil. J King Saud Univ - Sci, 25, 245250 https://doi.org/10.1016/j.jksus.2013.03.003 (2013).

37. Azzeddine, B. et al. Optimization and partial characterization of endoglucanase produced by streptomyces SP. B-PNG23. Arch Biol Sci, 65, 549-558 https://doi.org/10.2298/ABS1302549A (2013).

38. Rafael, L. et al. Production and characterization of endoglucanase secreted by Streptomyces capoamus isolated from Caatinga. African J Biotechnol, 15, 2394-2401 https://doi.org/10.5897/ajb2015.14610 (2016).

39. Zhu, Y., Chang, Y., Guan, J., Shanguan, G. \& Xin, F. Butanol production from organosolv treated spent mushroom substrate integrated with in situ biodiesel extraction. Renew Energy, 96, 656-661 https://doi.org/10.1016/j.renene.2016.04.048 (2016). 
40. Sun, S., Zhang, L., Liu, F., Fan, X. \& Sun, R. C. One-step process of hydrothermal and alkaline treatment of wheat straw for improving the enzymatic saccharification. Biotechnol Biofuels.11. https://doi.org/10.1186/s13068-018-1140-x (2018).

41. Toquero, C. \& Bolado, S. Effect of four pretreatments on enzymatic hydrolysis and ethanol fermentation of wheat straw. Influence of inhibitors and washing. Bioresour Technol, 157, 68-76 https://doi.org/10.1016/j.biortech.2014.01.090 (2014).

\section{Figures}
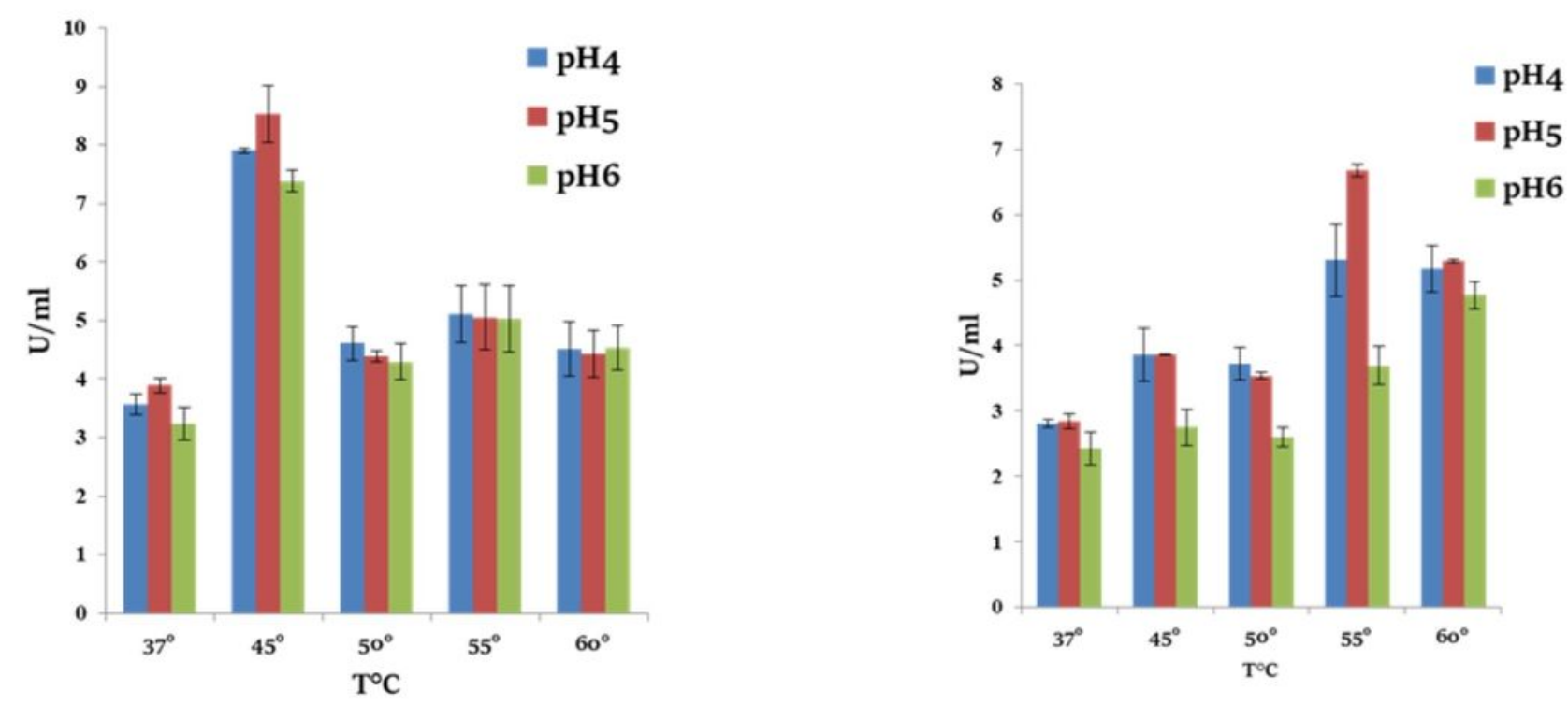

\section{Figure 1}

A Optimal temperature and $\mathrm{pH}$ of activity towards 4-Nitrophenyl $\beta$-D-glucopyranoside for Cel1 reported as $\mathrm{U}$ ml-1 and measured at $\mathrm{pH} 4,5,6$ and in a range of temperatures between $37^{\circ} \mathrm{C}$ and $60^{\circ} \mathrm{C}$; $\mathrm{B}$ Optimal temperature and $\mathrm{pH}$ of activity towards 4-Nitrophenyl $\beta$-D-glucopyranoside for Cel2 reported as $\mathrm{U} \mathrm{ml}-1$ measured at $\mathrm{pH} 4,5,6$ and in a range of temperatures between $37^{\circ} \mathrm{C}$ and $60^{\circ} \mathrm{C}$ 
A

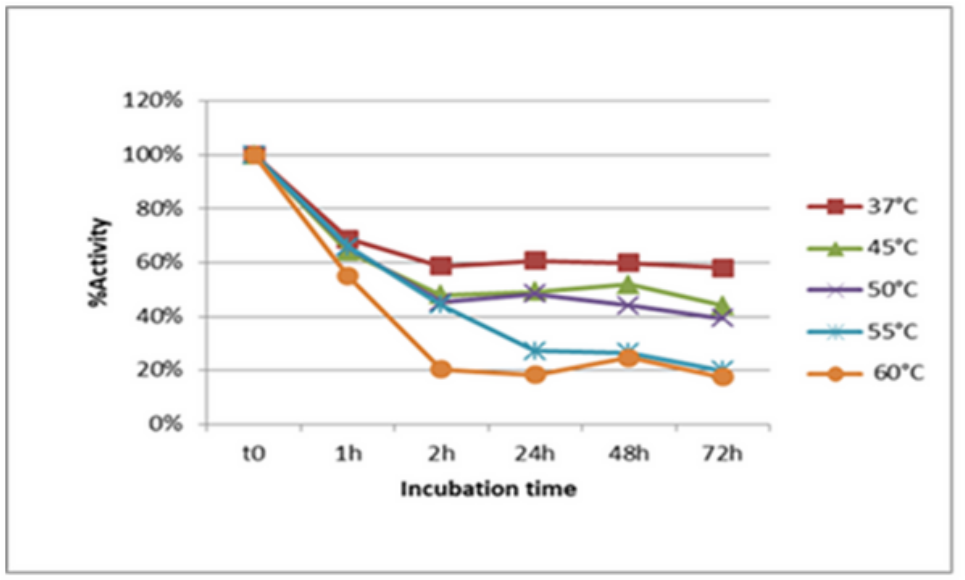

C

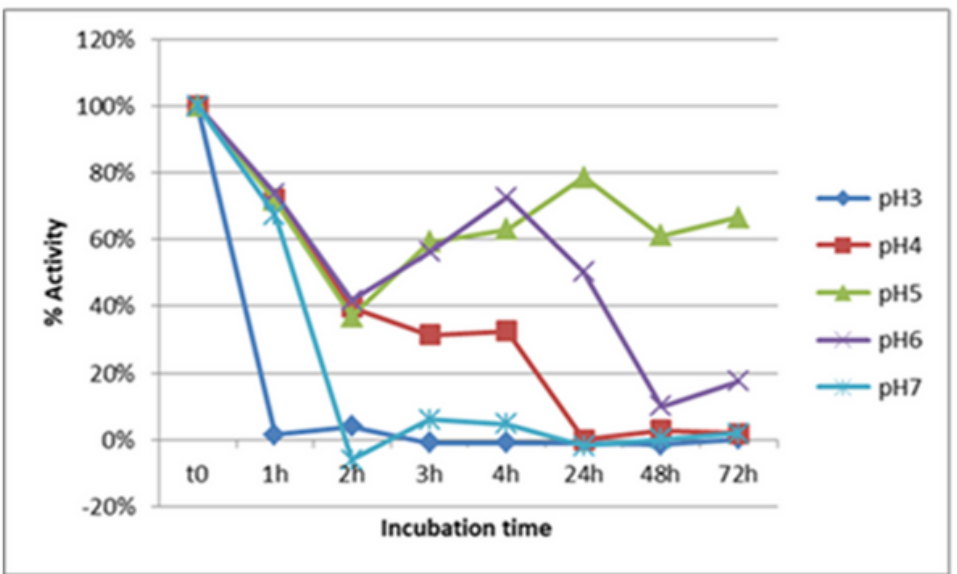

B

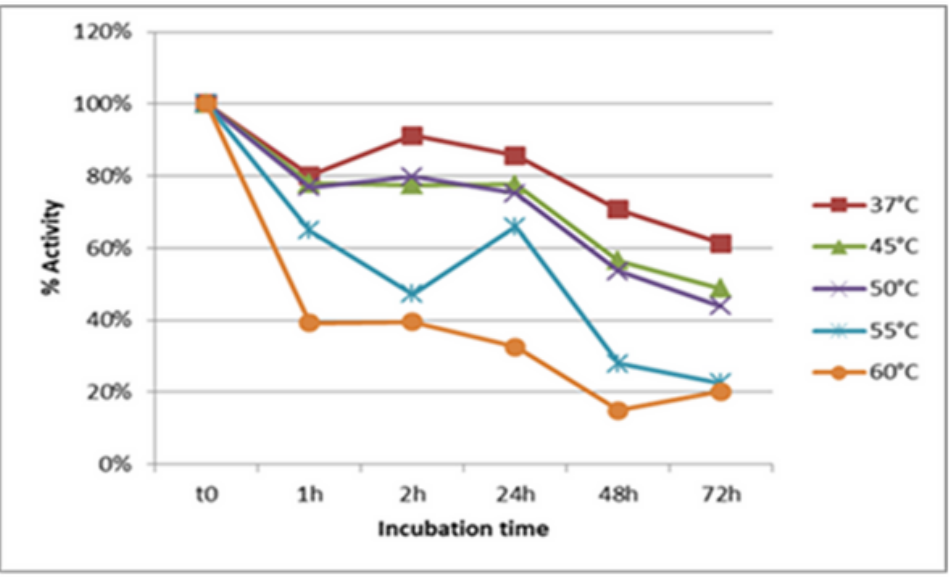

D

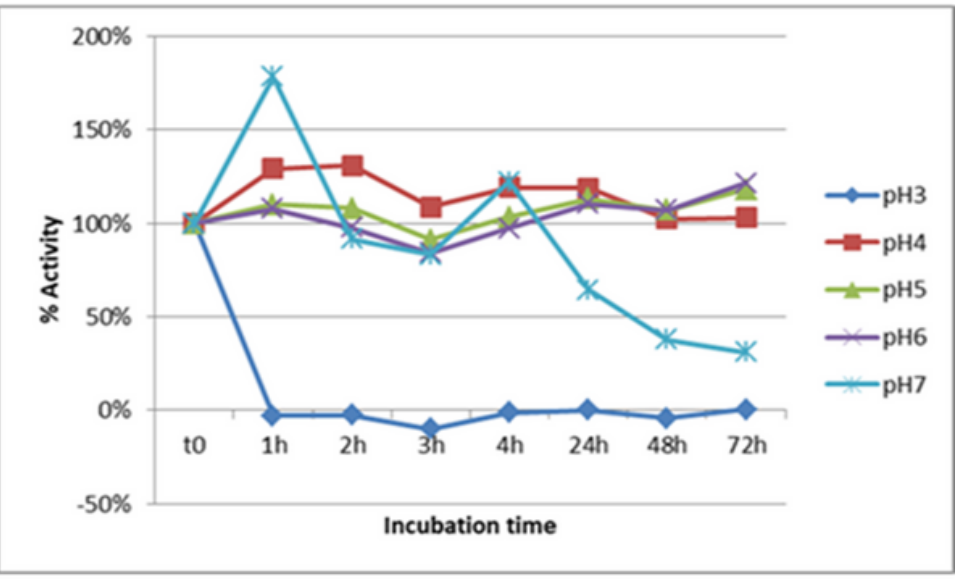

Figure 2

A Thermoresistance of activity towards 4-Nitrophenyl $\beta$-D-glucopyranoside for Cel1 evaluated for 72 hours in a range of temperatures between $37^{\circ} \mathrm{C}$ and $60^{\circ} \mathrm{C}$; B Thermoresistance of activity towards 4Nitrophenyl $\beta$-D-glucopyranoside for Cel2 evaluated for 72 hours in a range of temperatures between $37^{\circ} \mathrm{C}$ and $60^{\circ} \mathrm{C} ; \mathrm{C} \mathrm{pH}$ resistance of activity towards 4-Nitrophenyl $\beta$-D-glucopyranoside for Cel1 measured in a range of $\mathrm{pH}$ between 3 and 7 for 72 hours; $\mathrm{D} \mathrm{pH}$ resistance of activity towards 4-Nitrophenyl $\beta$-Dglucopyranoside for Cel 2 measured in a range of $\mathrm{pH}$ between 3 and 7 for 72 hours 


\section{Optimal pH measured at the optimal temperature}

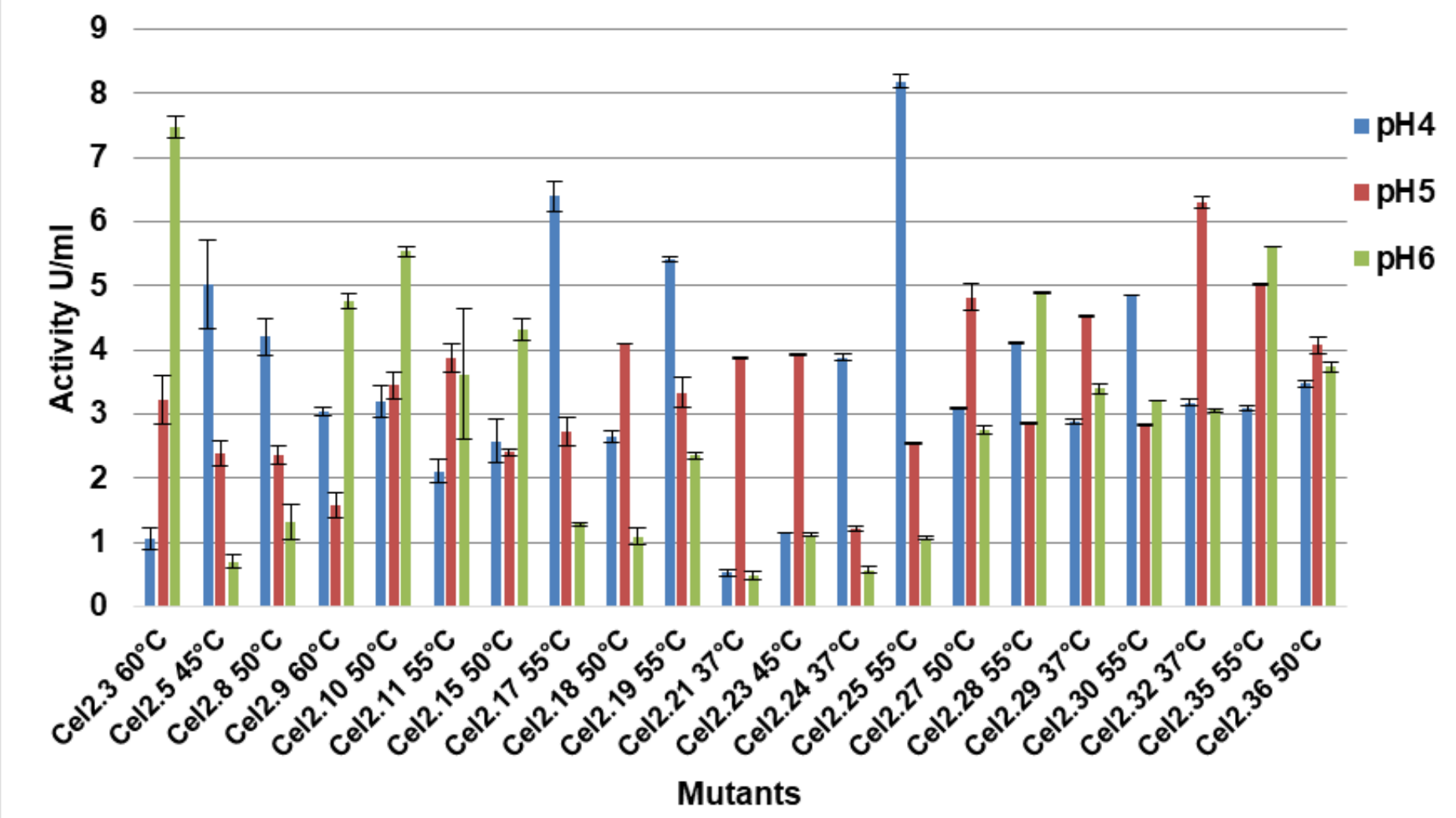

Figure 3

Optimal $\mathrm{pH}$ of activity towards 4-Nitrophenyl $\beta$-D-glucopyranoside for Cel2 mutants measured at the optimal temperature of each mutant at $\mathrm{pH} 4, \mathrm{pH} 5$ and $\mathrm{pH} 6$ 


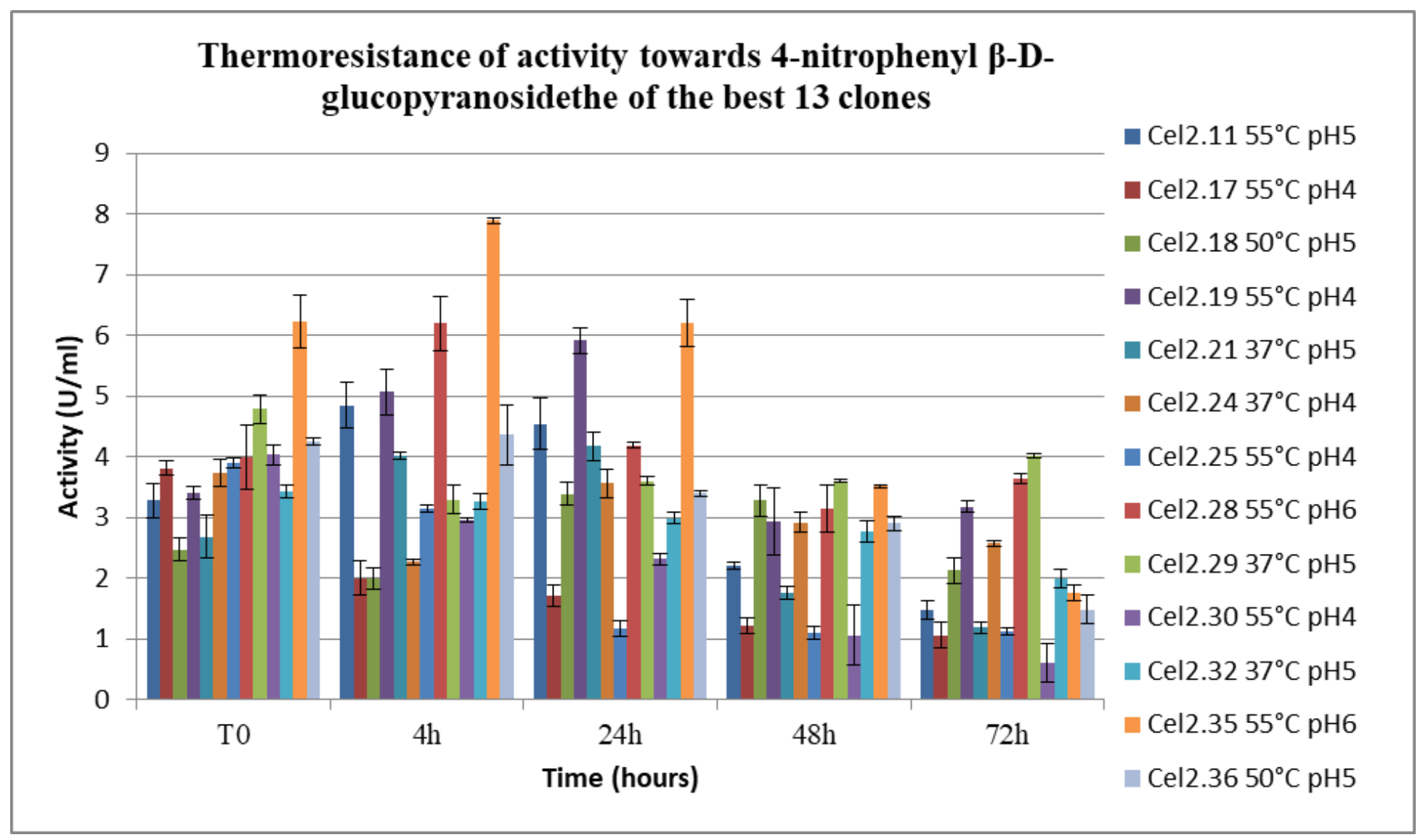

Figure 4

Thermoresistance of activity towards 4-Nitrophenyl $\beta$-D-glucopyranoside for the best 13 clones that maintained their activity after 72 hours of incubation at their optimal temperature and optimal $\mathrm{pH}$ 


\section{Hydrolysis SMS/WS (40:60) 72 hours}

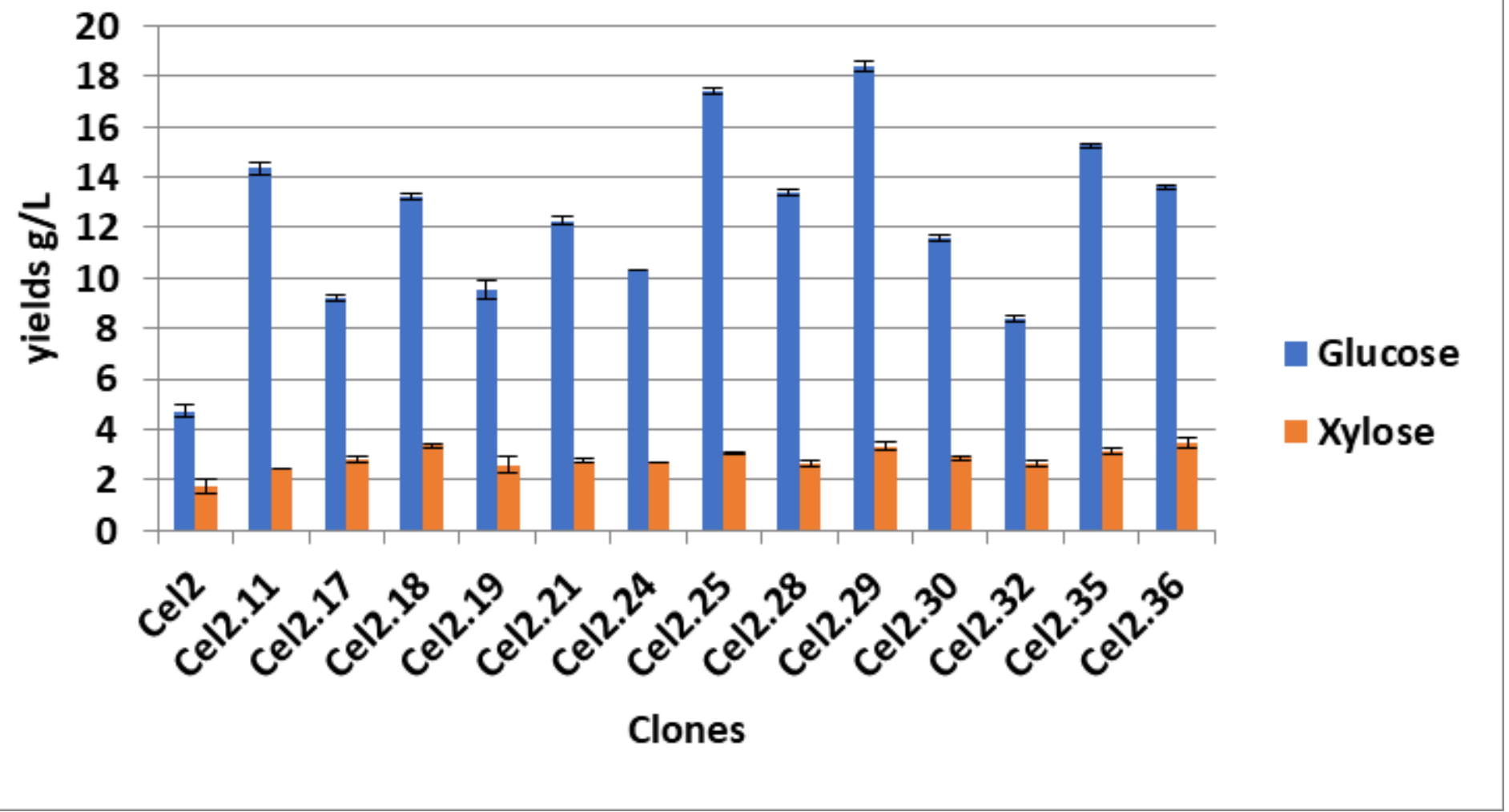

Figure 5

glucose and xylose yields (g L-1) after 72 hours of incubation of the 13 best mutants and Cel2 added to SUNO BOOSTER 144 with SMS/WS (40:60).

\section{Supplementary Files}

This is a list of supplementary files associated with this preprint. Click to download.

- SupplementarymaterialspaperMaurielloetal.docx 